\title{
Liberalization by Exhaustion: Transformative Change in the German Welfare State and Vocational Training System*
}

This article argues that two core domains of the German coordinated market economy have under gone transformative institutional change: the welfare state and the vocational training system. We argue that this process is best described as a process of liberalization resulting from the exhaustion of traditional institutions. Exhaustion describes a mechanism of institutional change in which endoge nous negative feedback effects, caused by the overextension of resources, lead to a transformation of the formerly symmetrical and consensual relationship between the state, employers and unions into an asymmetrical and conflictual one. The article contributes to the analysis of institutional change and applies the comparative method of the "parallel demonstration of theory".

Pension policy, vocational education and training, institutional change, exhaustion, liberalization

\section{Introduction}

After generations of studies had characterized Germany as a case of political gridlock and Reformstan because of its multiple institutional veto points, vested interests and cross class coalitions, nowadays more and more studies observe transformative rather than adaptive and incremental change in Germany's political economic institutions. This is particularly the case in social and labour market policy, industrial relations, corporate governance or the financial system (Cioffi/Höpner 2006; Deeg 2001; Pal ier/Thelen 2010; Streeck 2009; Trampusch 2009), but recently also in vocational training institutions (Busemeyer 2009; Thelen/Busemeyer 2012; Trampusch 2010).

This paper addresses this literature. On the basis of an in depth analysis of insti tutional change in two core domains of the German coordinated market economy vocational training and social policy we will demonstrate that it is indeed plausible to characterize the present changes in the German political economy as transforma tive. Our analysis differs from recent studies in two respects: First, contrary to Palier and Thelen (2010), who characterize the change as a process of dualization, we empha size the theoretical and practical value of the notion of liberalization (Streeck 2005, 2009). Increasing labour market stratification (i. e. "dualization") can be a conse quence of liberalization, but we believe liberalization is a better characterization of the kind of policies that governments of different political orientation have pursued in the last decades in Europe in general and in Germany in particular. Thus, we agree

* We are grateful to Bernhard Ebbinghaus, Bruno Palier and Kathleen Thelen as well as to two anonymous reviewers for helpful comments. 
with Thelen (2012) who speaks of "trajectories of liberalization" instead of conceptu alizing dualization as something inherently different from liberalization.

We define liberalization as a process of disburdening existing institutions of co ordinated capitalism from quasi public, collective obligations which entails a shift in the division of labour between the state and the market in providing and financing collective goods towards markets. Reinforcing the role of markets neither implies Germany's convergence to a liberal market economy, nor the total loss of solidarism and collectivism on the part of employers. Likewise, liberalization does not result in a retreat by the state or in totally weakened trade unions. In contrast, liberalization is a multi dimensional process which is "always accompanied by institution building, necessarily of a market accommodating and contingently of a market correction sort" (Streeck 2005: 4), hence, re regulation. Overall, it leads to a significant transformation of the role of the state.

As far as the explanation of this process of liberalization is concerned, we show that both in the fields of social policy and vocational training in Germany, institu tional change is driven by endogenous forces in the form of a particular mechanism, which we call exhaustion (see also the introduction to the volume by the guest edi tors). This notion implies that traditional institutions and policy solutions from the era of coordinated welfare state capitalism still exist, but their performance has changed, i.e. they become "exhausted". This produces new kinds of conflicts and cleavages which contribute to the further undermining of existing institutional arrangements. The un derlying causal mechanism is a process of negative feedback which stands in contrast with the kind of path stabilizing positive feedback processes emphasized in the welfare state literature (Pierson 2004). We argue that institutions even when actors continue to support their existence can generate negative and to a large part unintended side effects which have self undermining consequences in the long run.

Germany is a "typical" (in the sense of representative) case for the group of co ordinated market economies and conservative welfare states. Thus, studying devel opments in the case of Germany has implications for the study of other countries of this regime type. Defined in this inductive manner, according to Gerring (2007: 91), typical cases serve an 'exploratory role' and 'are helpful in exploring causal mecha nisms'. Therefore, our within case studies do not "test" theories in the conventional sense, but are aimed at generating theory, i.e. demonstrating the explanatory value of the notion of "liberalization by exhaustion". Methodologically, we apply the com parative method of parallel demonstration of theory (Skocpol/Somers 1980: 176). Instead of estimating the magnitude and direction of a causal effect across a large number of observations, which is the dominant approach in quantitative social science (Ma honey 2010), we focus on causal mechanisms. For that purpose, the parallel demon stration of theory in two policy fields, that are in many respects different from each other, is meant to show that similar developments can be observed in these two cases. Hence, we aim to "illustrate and clarify" and, "potentially, refine" theoretical accounts (i. e. our notion of liberalization by exhaustion) (Skocpol/Somers 1980: 191). By analyzing specific and significant reform processes in social policy and voca tional training policy, we believe we can generate insights into the changing dynamic of the German welfare state beyond these particular policies since the two areas have been central pillars of the German welfare production regime. 
This article is divided into five parts. On the basis of the literature on change in the German political economy and more recent concepts of institutional change developed within historical institutionalism (Campbell 2004; Streeck/Thelen 2005; Hall/Thelen 2009; Streeck 2009; Mahoney/Thelen 2010), the following section (part 2) develops the notion of liberalization by exhaustion. In the proximate two sections (parts 3 and 4) we reconstruct the process of liberalization in the welfare state and in vocational training and demonstrate the explanatory value of the mechanism of ex haustion. In the final section we discuss the implications of our findings for further research on institutional change in coordinated market economies.

\section{Liberalization by Exhaustion}

Drawing on recent work in the field (Streeck/Thelen 2005; Hall/Thelen 2009; Ma honey/Thelen 2010; Thelen/Kume 1999; see also the introduction to this volume for more references), we argue that any analysis of how and why institutions change should be concerned with the politics of institutional stability and change. This power distributional perspective makes, in our view, three conceptual advances: First, it points out that the maintenance of existing socio economic institutions "requires the ongoing mobilization of political support as well as, often, active efforts to resolve institutional ambiguities in their favor" whereas "one important source of change will be shifts in the balance of power" (Mahoney/Thelen 2010: 11). Second, institutions are regarded as "common carriers" (Pierson 2004: 109) for a multitude of interests. Actors or individual groups of actors support the maintenance of an existing institution because they perceive and value specific benefits that this institution creates (Hall/Thelen 2009: 14). This empirically grounded perspective on support coalitions opens up possibilities for complex dynamics of institutional change. Third, and directly following from this second aspect, similar to a shot gun, institutions may roughly "hit the target" favoured by the politically dominant coalition behind an institution's estab lishment, but they usually create a number of unintended side effects, some of which might be beneficial, whereas others trigger negative feedback effects.

How can we explain institutional change? Here, an important issue is to specify mechanisms of change (Streeck/Thelen 2005; Hall/Thelen 2009; Streeck 2009; Ma honey/Thelen 2010). Drawing on Jon Elster (1989: 3), causal mechanisms are the proc esses "that account for causal relationships among variables" (Campbell 2004: 63). They signify "bow one variable affects another" (Campbell 2004: 63; italics by Campbell).

Scholarship in institutionalism has identified a number of these causal mecha nisms such as path dependence, diffusion or "bricolage" (Campbell 2004: 62 89). However, we believe the mechanism of institutional "exhaustion" is particularly well suited as a conceptual tool to make sense of the kind of transformative institutional change to be observed in the German political economy. "Exhaustion" is not a new concept, but our intention is to refine and revive it. The notion of exhaustion stems from Streeck and Thelen (2005), Streeck (2009) and Trampusch (2005b, 2009). For Streeck and Thelen (2005: 29), exhaustion is associated with institutional breakdown. In more recent contributions to the theory of institutionalism (Mahoney/Thelen 2010), exhaustion is not included as a mechanism of its own anymore. In his analysis 
on institutional change in the German political economy, Streeck (2009: 138) replaces the concept of exhaustion with that of "decay". He only uses the term exhaustion to signify the overload of public finances and of the old social policy institutions.

However, in our view, the concept of institutional exhaustion can and should be revisited for four reasons: First, exhaustion describes a causal mechanism which drives processes of change as a consequence of endogenously generated negative feedback effects. Second, this concept enables us to specify the precise interaction between exogenous and endogenous sources of change by pointing to the role of exogenous factors in influencing the timing of transformative change. Third, we claim that "exhaustion" is different from full scale institutional breakdown, displacement or systemic "decay" (Streeck 2009: 138). Exhaustion captures a significant reduction in the performance and functioning of a given set of institutions that may neverthe less be politically sustainable. Fourth, exhaustion also differs from the other three types of transformative change suggested by Streeck and Thelen (2005) as well as by Mahoney and Thelen (2010): Exhaustion differs from institutional layering and con version because institutional rules are cut down and just not replaced by new ones with the same function (layering) or adapted to new functions (conversion). In con trast to change by drift, policy makers are actively engaged in maintaining traditional institutions and adopting them to a changed environment, but in doing so, they inad vertently promote institutional transformation.

Using stylized facts from the German case, the causal mechanism of exhaustion plays out according to the following pattern: Cross class coalitions of employers, unions and state actors have been crucial supporting pillars of the German model of coordinated, corporatist welfare state capitalism. The support of the state was crucial in order to maintain the commitment of the social partners to the corporatist com promise. Over time, however, the corporatist approach to policy making led to the accumulation of negative side effects as the social partners started to pursue more particularistic instead of collective interests, effectively forcing state actors to deal with the ensuing negative externalities. In the case of welfare state policies, the gen erous subsidization of early retirement contributed to increasing non wage labour costs and mounting public debt; in the case of vocational training, the superior status of firm based training and the rejection of school based alternatives in vocational education aggravated the crisis on the apprenticeship market. The accumulation of negative side effects could be ignored for a while in part because the perception of the relevant political actors was biased in favour of existing institutions. As we show later, at some point the negative side effects and growing tensions reached a critical threshold which led to the re alignment of interests and subsequent shifts in the balance of power and the dynamic of supporting coalitions.

How did the government react to the "exhaustion" of corporatist institutions? In principle, the reaction could have been a move towards a more static, centralized (Scandinavian or Social democratic) model of welfare state capitalism and state run training. However, as we will see below in the case studies, it seems more adequate to characterize the direction of transformative change as a process of liberalization.

Liberalization as such is associated with the formation of new coalitions and the redrawing of the boundaries of old ones. For this reason the liberalization of German coordinated capitalism will not lead to powerless unions, free market employers or a 
weak state. Rather, liberalization is associated with a change in the role of the state because the boundaries between politics and the markets are redrawn by deregulation as well as re regulation. What we find in our case studies is a re assertion of the role of the state and a renewed involvement on the part of state actors in the running of the economy and the welfare state that is different from its previous stance. Drawing on Polanyi (1944) and Streeck (2005, 2009), deregulation is "always accompanied by institution building, necessarily of a market accommodating and contingently of a market correction sort" (Streeck 2005: 4). That means that even processes of deregu lation (or liberalization) are generally accompanied by a re assertion of the role of the state. Furthermore, this re assertion of the state is not directed at abolishing the es tablished institutions of coordinated capitalism, but at maintaining and adapting them to a changed context. The role of the state is also different from a centralized, statist model of welfare state capitalism because the state continues to delegate public respon sibilities to economic actors. The crucial difference to the former model is that corpora tist institutions have become less encompassing and more focused on the maximization of competitiveness instead of generalized political exchange. Thus, the process of active preservation through adaptation promotes the further transformation of the institutions of coordinated capitalism because the hierarchical intervention of the state is funda mentally at odds with the corporatist political process of the old model.

In the following sections, we will provide case studies on the process of liberali zation for two domains in the core of the German political economy: the welfare state and vocational training. The purpose of these case studies is to show that we can observe parallel developments in these policy fields. Analytically, both narratives are constructed in a similar manner: In a first step we sketch the main features of the old institutional arrangements in the corporatist welfare and training regimes. In a second step we describe the direction of change as transformative processes of liber alization by exhaustion.

\section{The Welfare State}

For decades, the German welfare state was viewed as being the prototype of a path dependent, corporatist, and conservative Bismarckian welfare state. There were three institutional dimensions which formed the foundation of the German corporatist welfare state model until the mid 1990s: social contribution based financing, the dependency of benefits on earnings (with status maintenance) and employers' and trade unions' involvement in policy making and administration of social policy ( $\mathrm{Pal}$ ier/Martin 2007: 537; Hassel/Schiller 2009: 2). In the following section we will first describe the functioning of these main institutional dimensions during the heyday of the German welfare state. Then we show how in the wake of German unification and since the mid 1990s, these dimensions have undergone a transformative process of change because the accumulation of negative side effects (increasing non wage labour costs and mounting of public debt) resulted in a significant reduction in the perform ance and function of the old welfare model. 


\subsection{Welfare Corporatism until the mid-1990s}

Until the mid 1990s, the principle of social contribution based financing, the de pendency of benefits on earnings (with status maintenance) and employers' and trade unions' involvement in policy making and administration of social policy helped to cement a cross class and cross party alliance between social politicians, employers, trade unions, works councils and public social policy administrators (for details see also Manow/Seils 2000: 265 266). This alliance following Streeck (2009: 56 67) we call it "welfare corporatism" was in favour of offloading the costs of industrial restructuring, rationalization and German unification, first onto the social insurance funds, and later, with the de legitimization of a further rise in social insurance contri bution rates, onto the federal budget as well.

The alliance's motor was that the interest on the part of social partners in exter nalizing the costs of adjustment colluded with government's motivation to shift the costs of industrial restructuring out of the federal budget and onto the social insur ance funds (Manow/Seils 2000: 265 66). This interest collusion was reinforced by strong structural ties between politicians and social partners (Trampusch 2005a) fa cilitating not only cross party consensus in social policy, but also assuring a strong position for employers and trade unions in the process of policy formulation (Tram pusch 2009: 87 103).

In West Germany the main period of this alliance was during the heyday of the Modell Deutschland in the 1970s and 1980s, the success of which was based on a subtle interaction between the welfare state, the system of collective bargaining and the federal budget (Manow/Seils 2000: 265). In the 1990s social security helped the country to cope with the socio economic and political challenges caused by German unification. Manow and Seils (2000) and others (Mares 2003; Streeck 2003; Has sel/Schiller 2009; Trampusch 2009) have shown how in the 1970s and 1980s unem ployment insurance, labour market policy and the pension system were used as means of reducing labour supply in order to tackle employment problems in the wake of the oil crisis. Across a range of industries, early retirement financed by pension and un employment insurance became the preferred solution for managing large scale lay offs. In the 1980s the use of pension and unemployment insurance for early retire ment expanded further as a result of legislation to strengthen the link between bene fits and contributions in the unemployment insurance (Äquivalenaprinzip). German unification exported welfare corporatism and with it the three main institutional dimensions to eastern Germany. Measures used in West Germany to restructure firms and sectors were now extended in order to restructure a whole socialist econ omy into a market economy.

\subsection{The Accumulation of Negative Side Effects}

The consensual politics of welfare corporatism should not belie the strains with which the German welfare system had already been confronted at the end of the 1980s. As early as the 1980s dissatisfaction with early retirement financed state social policy had increased. The federal government accused German business of abusing the law and sought to change regulations to make firms share the costs (Trampusch 
2009: 118 119). As far as the political parties were concerned, the liberal FDP in particular and the economic wing of the CDU demanded reforms and a $U$ turn in social policy (Trampusch 2009: 111 112). As a result, on the eve of the Manerfall, reform decisions were made to reduce the (mis) use of the pension system for early retirement (Trampusch 2009: 111 112). These reform attempts were halted, however, by the strong euphoria of German unification, but they returned with the recession of 19921993 and the severe fiscal constraints caused by unification. In eastern Ger many labour market programs expanded to unprecedented levels (Manow/Seils 2000: 293) adding to non wage labour costs and generating a spiral in which the very policy that was intended to fight unemployment became a potent contributor to it. The aggregated sum of social insurance contributions increased steadily and by $1996 \mathrm{ex}$ ceeded the magic figure of 40 percent of gross wages (Trampusch 2009: 115). Be tween 1990 and 1998 alone the combined social insurance rate grew by six and a half percentage points, from 35.5 to 42.1 percent, of which German unification accounted for about three percentage points (Trampusch 2009: 115). German unification had such a big impact because it amplified strains that were already present in the old Western German model.

The rise of non wage labour costs (mainly in the wake of German unification) resulted in three fundamental tensions which broke up the agreement between politi cal parties and employers on the German social model: First, unification resulted in "increasingly severe resource constraints" (Streeck 2007: 5) for public finance, disin tegrating the cross party consensus on welfare corporatism. Second, a strife within the party system developed as the liberal FDP in particular and the economic wing of the CDU demanded reforms and a $U$ turn in social policy to reduce the (mis)use of the pension system for early retirement (Trampusch 2009: 111 12). This strife strongly exhibits the tensions generated by the decreasing returns of the old institu tional model. Third, a rift was opening within Germany's employer associations' as small firms and the Mittelstand (who colluded with the liberal forces among political parties) were adversely affected by rising non wage labour costs. Large firms contrib uted massively to this problem through the widespread use of early retirement to trim their workforces, making up for its effects through productivity gains as a result of working time arrangements and rationalization (Streeck 2003: 6). A gap opened up between big firms and small firms. Smaller firms could not capitalize on the advan tages of early retirement because they could not afford the voluntary redundancy payments (Mares 2003: 238). These tensions polarized Germany's employers' associa tions because small and medium sized firms rebelled and challenged the traditional dominance of large companies.

As a consequence, the social model was put under considerable political and public pressure. A look at the figures shows that the fiscal pressure was quite real. As result of German unification, the refunding of the social insurance system by taxes and the federal budget increased. For example, while in 199523 percent of pension benefits paid were funded by federal subsidies from general taxes; by 2004 this share had risen to 37 percent, or 77.4 billion Euros (Streeck 2007: 13). Without these public subsidies, the pension insurance contribution rate would have to be 28.4 percent instead of 19.5 percent, producing a combined contribution rate of almost 50 percent (Streeck 2007: 13). In the 1990s the fiscal manoeuvres between the social insurance 
budgets entered a new phase (Trampusch 2009: 147). In order to avoid a collapse of the social insurance system and a further increase of the combined contribution rate, the government balanced the social budget by increasing the level of cross subsidization out of the federal budget.

\subsection{Transformative Change and Liberalization}

Both Kohl (1994 1998) and Schröder (1998 2005) unilaterally enacted far reaching reforms in pensions and in the labour market. Increasing refunding of social insur ance out of the federal budget, the "Hartz reforms", Agenda 2010, as well as the pension reforms of 1997 and 2001 have fundamentally challenged the first two main principles of the German social model that is, its contribution based financing and the dependency of benefits on earnings (with status maintenance) (for a similar ar gument, see Hassel/Schiller 2009: 2). Furthermore, the social partners' influence in policy making and administration of social policy was rolled back decisively and the last attempt at negotiated reforms totally failed.

Contribution-based Financing and Dependency of Benefits on Earnings

The principles of contribution based financing as well as the dependency of benefits on earnings had been weakened in a fundamental way already during the last Kohl government. Also, the social partners' influence on social policy was reduced; how ever, it was only under the Schroeder government that this third principle (see next section) was dramatically challenged as well.

By 19951996 the welfare system had clearly become untenable. Due to increas ing non wage labour costs, the German labour market was confronted with a grow ing number of unemployed workers, which drove social insurance contribution rates up further. Rising non wage labour costs and unemployment strained the loyalties of employers' and trade union constituencies. Facing increased pressure from small and medium sized firms and his own liberal coalition partner, the FDP, Chancellor Kohl made curbing early exit a governmental priority. The BDI (Bund Deutscher Industrie, Association of German Industry) and the economic wing of the government coalition (a group of CDU/CSU members of the Bundestag based around Wolfgang Schäuble, together with the FDP) exerted strong pressure on the Chancellor to lower non wage labour costs through social policy reforms (Streeck 2003: 14 15). With the aggressive style of this "yes we can" reform coalition, the consensus boom, which unification had generated, resulted in a struggle between Kohl and the labour wing of the $\mathrm{CDU} / \mathrm{CSU}$ on the one hand, and liberal business associations and politicians in the FDP and CDU/CSU on the other hand.

The result of this pressure was the so called "Action Program" of 1996 worked out by FDP Economics Minister Günter Rexrodt. Due to the demands of the Liber als and the economic wing in the CDU, however, the program not only intended to reform the early retirement regime. It also included a deregulation of the labour law through changes in the dismissal law and the cutting of sickness benefits, which trade unions perceived as part of their identity. All in all, these reforms fundamentally altered the generosity of the welfare system by reducing benefits and thereby ques tioning the principle of status maintenance in case of health problems and early re 
tirement. In 1997 the trajectory of benefit cuts was continued and amended by a deliberate weakening of contribution based financing. On the one hand, at the end of 1997 and under the pressure of the rapid increase in non wage labour costs since unification, an increase in the pension contribution rate was avoided by raising the value added tax from 15 to 16 percent. On the other hand, the Kohl government put unions on edge by breaking with the traditionally consensual style of pension policy (Schludi 2005: 150 151). The government enacted a pension reform with significant cuts in benefits. Against the resistance of the oppositional SPD, a so called "demo graphic factor" was introduced which was aimed at taking into account the increase in life expectancy.

Kohl's reforms contributed to the success of the Social Democrats in the 1998 Bundestag election (Schludi 2005: 153). During the election campaign the SPD had promised to undo the cuts in benefits. In his first two years of office Chancellor Gerhard Schröder turned back the clock (Trampusch 2009: 136). The government also lowered the rate of contributions to pension insurance from 20.3 to 19.5 per cent, even though the suspension of the Kohl reforms was bound to cause higher expenditures. However, starting in 2001 with the pension reform which introduced private pension schemes and cut back public pensions, Schröder's reforms followed the liberalization trajectory by shifting the division of labour between the state and the market to market relations and unilaterally enacting dramatic cuts and deregula tions in public social and labour market policy. The process of liberalization involved a fundamental restructuring of the Federal Labour Office, the loosening of protec tions against layoffs and overtime, the promotion of non standard employment and severe cuts in social benefits (for a similar description, see Vail 2008: 335, 346 347). Coming back to our three institutional dimensions which signified the traditional German welfare state, the Schröder government continued on the path already pur sued by the Kohl government, adding the exclusion of social partners in the social policy making process and its administration.

The pension reform, enacted in 2001 with support of the chemical union and in opposition to the IG Metall, became one of the more lasting projects of Schröder's first term in government. It encouraged workers to take out either private or occupa tional, employer based additional pension plans (labeled Riester Rente), helped by a government subsidy of up to 10 billion Euros per year. Since 2002 employees can put one percent of their pay into a private savings account and up to four percent in 2008 (so called Entgeltumwandlung, payment commutation). However, government subsidies for such accounts are conditional on the existence of a collective agreement by which Entgeltumwandlung is regulated (the so called Tarifvorrang). The party responsible for this part of the reform was the union of chemical workers, IG BCE, which had al ready concluded collective agreements on pensions in 1999 and was eager to protect its approach. To this extent, Riester's pension reform is the result of successful lob bying of the Ministries of Labour and Finance by a moderate trade union and against the opposition of the metalworking union which still favoured the old social model. It is important to note that before becoming Minister of Labour Walter Riester was vice chairman of the IG Metall and in this position he represented the moderate wing of this trade union. The 2001 pension reform has moved the German pension system 
from a public pay as you go system towards a more privately funded system, thereby also weakening the principle of social contribution based financing.

As was the case in pension reform, this unilateral strategy also found its way into labour market reform policy. A first step towards a reform of the public employment service was not provoked by negotiations but by the so called placement scandal at the Federal Labour Office (Bundesagentur für Arbeit). After the Bundestag election in September 2002, two "Acts Promoting Modern Labour Market Services" (commonly referred to as "Hartz I" and "Hartz II") passed the Bundestag and Bundesrat. Under the legislation, the rules determining which jobs an unemployed worker was allowed to reject (Zumutbarkeit) were tightened and so were the conditions for claiming un employment assistance. In addition, workers facing unemployment were required to report earlier to the local employment service. Moreover, the reform raised the earn ings limit for low paid work exempt from social insurance contributions (Mini Jobs) and introduced a scale of rising contribution rates for monthly incomes between 400 and 800 Euros. Finally, the legislation provided for the creation of temporary em ployment agencies based on the Hartz model, which liberalized and deregulated job placement (Eichhorst/Kaiser 2006: 13). Most importantly, however, the Hartz pack age also included a fundamental internal restructuring of the Federal Labour Office (Bundesanstalt für Arbeit), thereby also fundamentally weakening the influence of social partners in this organization (Trampusch 2009: 8).

Hartz III and IV relaxed employment protection for small firms and, through the supplementary reforms of the Agenda 2010, shortened the duration of unem ployment benefits (Arbeitslosengeld) to a general maximum of 12 months (18 months for persons aged 55 or more), instead of the former 32 months. The most far reaching measure of the Hartz reforms was Hartz IV, the amalgamation of unem ployment assistance and social assistance into a single, flat rate and means tested benefit calculated according to principles of social assistance (Arbeitslosengeld II). This reform resulted in the abolishment of status protection for the long term unem ployed, replacing it with a means tested flat rate benefit (Eichhorst/Kaiser 2006: 9). This was one of the main important attacks on the principles of benefits depending on earnings and status maintenance.

Unexpectedly re elected in 2002, Chancellor Schröder, in a speech to the Bundestag in March 2003, announced his "Agenda 2010", a package of measures intended to make the German economy more "flexible" and competitive. In addition to tax cuts and vague promises to make it easier for firms to opt out of sector wide industrial agreements, the "Agenda" focused on the three big pillars of the German welfare state: pensions, health care and unemployment insurance. It included a reduc tion in Germany's generous unemployment and sickness benefits and proposed mak ing it easier for small companies to hire and fire new workers. The Agenda 2010 reinforced long existing internal divisions between "modernizers" and traditionalists in the trade unions (Trampusch 2009: 99, 144 146).

It is important to note that this shift to market relations in social policy was ac companied by market correcting policies which have partially relocated the financing and provision of pensions and early retirement in collective agreements (Trampusch $2005 \mathrm{~b}, 2009)$. In the context of the unilateral government interventions to restructure the social policy arena, it was the chemical union which agreed to accept a link be 
tween social policy and collective bargaining and thus also helped to absorb the costs of social policy through wage compression. These agreements were encouraged by the government's pension and early retirement reforms through direct public pay ments and tax deductions (Trampusch 2005b).

\section{The Breakdown of Social Partners' Influence}

The breakdown of welfare corporatism we have just described is most importantly reflected in a fundamental weakening of the linkages between political parties and social partners. One of the main indicators of these weakening links is the profound elite change, which has taken place in the Bundestag's Standing Committee for Labour and Social Policy (Trampusch 2005a). In the 1970s and 1980s the Committee mem bers had strong links with social policy organizations. In the 1990s the careers of social policy experts in the Bundestag showed a trend towards generalized profession alization, which is characterized not only by fewer affiliations with social policy or ganizations. The Committee is now filled with members for whom their professional career as a politician stands in the foreground and for whom social policy is just a means to achieve a career in politics. In the 1990s German social politicians had less professional experience in social policy and more professional experience in politics. The weakening of these links points to the fact that, in contrast to the 1970 s and 1980 s, there is no relatively homogeneous group with common experience in the implementation of social policy that defines the political reform agenda in the $1990 \mathrm{~s}$. This change particularly reduced the influence of trade unions in the process of for mulating social policy. It is important to note that not only the linkages were weak ened, but that within political parties, the social wings became fragmented and weaker (Trampusch 2005a; Clemens 2007: 226). At the same time that the power of the Sozialpolitiker was reduced, a fundamental restructuring of self administration took place, further decreasing the power of trade unions. The Hartz reforms nearly abolished self administration in the BA (Bundesagentur für Arbeit, Federal Employment Agency) and in the areas of pension and health insurance, self administration was also considerably weakened (Trampusch 2009: 156 62). Hence, we argue that the decline of representational links between unions, employers and the social politicians of Germany's major political parties made reforms easier.

It is important to note that the elite change and the weakening linkages between trade unions and social politicians clearly signals a fundamental restructuring of the linkages between political parties and interests groups which was affected by several causal factors (on the following see Trampusch 2005a): On the one hand, there is a professionalization on the side of political parties caused not only by strategic deci sions of party leaders, but also by changed voters and interest groups preferences. On the other hand, it is just the diversification of interest groups' interests and prefer ences the intensified tensions in the employers and unions camps on welfare state reforms we discussed above which discouraged interest groups to build up stable patterns of territorial representation with politicians.

All in all, the reforms enacted by the last Kohl government and the Red Green government since 2001 have fundamentally altered the "important institutional" dimensions which have sustained the old German social model. Not only have the principles of social contribution based financing and dependency of benefits on earn 
ings (with status maintenance) been weakened, but employers' and trade unions' in volvement in policy making and administration of social policy has also been reduced.

\section{Vocational Training}

German vocational training has undergone a process of liberalization that has pro ceeded in an incremental fashion for a long period of time, but gained pace signifi cantly during the last years. We trace the developments along three dimensions that have been identified as crucial components of the German model of vocational train ing (Thelen/Busemeyer 2012; Busemeyer 2009; Busemeyer/Trampusch 2012; Tram pusch 2010): the combination of school based and firm based components of voca tional training, the certification of vocational qualifications according to the "occupa tional principle" (Berufsprinzip) and the corporatist framework of decision making in which the state establishes a regulatory framework and delegates significant compe tencies to the social partners. ${ }^{1}$

\subsection{The Era of Neo-Corporatist Compromise}

In historical terms, cross class compromise had always been more pronounced in the field of vocational training than in other domains such as collective wage bargaining or social policy (Mares 2003; Thelen 2004). Although the reform of vocational train ing was certainly accompanied by political struggles at times, in particular in the 1970s, a corporatist consensus emerged by the early 1980s that was further solidified after the change in government to a coalition of Christian Democrats (CDU) and Liberals (FDP) in 1982 (Busemeyer 2009: 106 126). The government decided to refrain from interfering too much with the autonomy of firms in matters of voca tional training. In particular, crucial decisions on the number of apprentices to be hired or the occupations they were trained in were completely left to employers. Thus, the individual firm was (and is) free to decide whether to hire apprentices at all, how many apprentices to hire, how many of those to retain after the completion of training and in which of the more than 300 officially recognized and certified occupa tions the apprentices will be trained.

Despite the recognition of firm autonomy in training, the government provided crucial support in the form of public policies. For example, it provided subsidies for out of firm training institutions in order to support the training efforts of small and medium sized firms and established the institutional framework needed to negotiate the reform of training ordinances in a complex process of corporatist and intergovernmen tal bargaining (Busemeyer 2009: 96 98). Most importantly, the government respected the autonomy of the social partners (unions and employers' associations) in reforming

1 Busemeyer and Trampusch (2011) add a fourth dimension: the extensiveness of firm involvement, which differentiates collective skill formation systems from segmentalist va rieties. Although important in general, this dimension is less relevant in the present case because we focus on policy making. 
training ordinances (akin to the principle of Tarifautonomie in the field of collective wage bargaining). Formally, these ordinances are ministerial decrees, so that the government can, in theory, decide to implement them without the consent of the social partners. However, the Christian Democratic governments under Chancellor Kohl made the consent between the unions and employers' associations a necessary precondition for the reform of training ordinances, even if, as in the case of metal and electrical occupa tions in the 1980s, the negotiation process lasted longer than 10 years (Streeck et al. 1987). The government believed that the respect for firm autonomy in matters of voca tional training was the crucial precondition for maintaining the commitment of em ployers to providing apprenticeship training (Bundesregierung 1983: 3).

Unions and employers were part of the encompassing corporatist compromise. Although they had supported the more ambitious reform agenda of the SPD led government in the 1970 s, unions came to accept the fact that ultimately, firm auton omy in training matters is necessary to maintain the commitment of employers to vocational training (Busemeyer 2009: 96 97). One reason for the increased union support for firm based training instead of school based alternatives was the fact that unions "discovered" the benefits of workplace based training, such as the smoothing out of the transition between training and subsequent employment. Another reason for the unions' support for the firm based training system was the strengthening of the position of unions in the reform of training ordinances and in the implementa tion of these ordinances on the firm level. The employers, in turn, accepted the intru sion of unions and policy makers into the realm of firm autonomy because they benefited from the support provided by targeted public policies and they valued the "specific" skills provided by workplace based training compared to other forms of vocational training and social peace (Streeck 1992; Hall/Soskice 2001: 39 41). How ever and this can hardly be overestimated the support of employers for the collec tive training regime depended on the continued respect of unions and policy makers for the fundamental principle of firm autonomy in training decisions. If the intrusion of policy makers reached a critical threshold, employers could still simply decide to stop offering training or, given the increasing age of apprentices, train them by means of particularistic on the job training instead of recognized training occupations.

In sum, by the 1980s, the vocational training system rested on an encompassing corporatist compromise between unions, employers and the state. With regard to the three dimensions introduced above, along which institutional change can be traced, the vocational training system in the neo corporatist era of the 1980s was character ized by: First, the predominance of apprenticeship training as the preferred educa tional choice for a majority of young people; second, a system of more than 300 recognized occupational profiles; and third, the maintenance of common standards in training, which required a strong, yet flexible institutional framework in which public oversight over training was delegated to the semi public Chambers of Industry and Commerce. Seemingly, the arrangement was stable as it provided concrete benefits for all concerned. However, as we will show in the following section, it produced negative side effects that accumulated over time, contributing to the endogenous transformation of the system in recent years. 


\subsection{The Accumulation of Negative Side Effects and the Transformation of Vocational Training}

As we argued above, the maintenance of central institutions of coordinated capitalism in Germany rested on cross class coalitions that proved to be inherently unstable instead of self reinforcing because they contributed to the accumulation of negative side effects to the detriment of those that were left out of the supporting coalition. In the case of vocational training, the core institution supported by the cross class coali tion was the principle of firm autonomy in training decisions. This led (or at least contributed) to the accumulation of negative side effects in the form of a structural excess demand for apprenticeship training places and did not prevent a gradual re treat of firms from vocational training.

To put some numbers on these developments, the share of firms participating in apprenticeship training declined from 34.4 percent in 1985 to 25.3 percent in 2005 (Busemeyer 2009: 41). In particular, smaller firms stopped hiring apprentices, whereas the participation rate of larger firms remained roughly constant (see also Thelen/Busemeyer 2012). As a consequence of this partial retreat of firms from training, the number of new apprenticeship contracts per year dropped from 595,000 in 1992 to 576,000 in 2006 (followed by a certain increase in recent years due to beneficial economic circumstances). But more important than the number of new training contracts is the number of young people who failed to get access to training. The number of youths participating in alternatives to firm based vocational training increased significantly: In 1992, 305,000 young people ended up in various training programs and preparatory courses that are supposed to ease the transition between school and training, but often lead to educational dead ends and "waiting loops" (Baethge et al. 2007). By the mid 2000s, the number of these youths had almost dou bled to about 600,000 , which is a strong indication of structural excess demand for training places. Even in the context of a tightening labour market, the number of youths in the so called "transition system" remains significant (about 300,000 in 2011, see Busemeyer 2012: 17) and is an indicator of transformative change in the relationship between school based and firm based vocational training.

As in the case of welfare state policies, exogenous shocks like German unifica tion certainly were important triggers of change. In the 1990s, the federal states in East Germany suffered from a particular shortage of apprenticeship places. The effects of unification, however, were more indirect than direct and interacted with deeper lying forces of endogenous change (see Busemeyer 2009: 127139 for details). Besides unification, structural changes in the economy such as de industrialization and economic globalization certainly had a negative impact on the willingness of firms to participate in training (Busemeyer 2009: 62 77). Demographic changes in the size of the relevant age cohorts, in particular in the early 1980s and the late 1990s, put additional strain on the training market. However, simply looking at these exogenous and socio economic forces does not help us to understand how these forces have set in motion the institutional transformation of the German training model and why this transformation results in liberalization. This is where the causal mechanism of ex haustion comes into play. 
The Relationship between School-based and Firm-based Vocational Training

Initially, the various school based vocational courses and labour market measures that today make up the bulk of the transition system were established in order to compensate for temporary shortages on the apprenticeship market. The relevant stakeholders in the corporatist compromise unions, employers, and the state were opposed to establishing a fully fledged school based alternative route to vocational qualifications because this would have threatened the crucial principle of firm auton omy at the core of the corporatist compromise. The transition system was thus never intended as a real alternative to firm based apprenticeship training, but as a safety valve to ease the pressure in the apprenticeship market.

This, however, has led to an increase in the relative status and privilege of firm based training. Although at first glance, the expansion of alternatives to regular ap prenticeship training seems to tilt the balance in favour of school based or out of firm training, this expansion actually made it harder to get access to firm based train ing. Policy makers have been very careful to avoid direct competition between ap prenticeship training and the alternatives. The qualifications and skills acquired in the preparatory programs are generally not recognized on the labour market, and appren tices do not get credit for them in case they start a regular apprenticeship afterwards (Euler/Severing 2006).

The overall effect of this development is to strengthen a hierarchy of more and less attractive vocational training alternatives. Before the onset of rationing on the training market, the large majority of school leavers willing to take up apprenticeship training could do so although, of course, there had been an informal hierarchy of more and less attractive places, e.g. between large firms and local crafts firms (Soskice 1994). The expansion of the transition system, however, exacerbated the formal hierar chy of alternatives in post secondary education with firm based apprenticeship training clearly at the top. This process can be understood as liberalization because the hierarchy of alternatives in vocational training mirrors market relationships to a larger extent than the regulated, undifferentiated and somewhat inflexible system of the 1970s and 1980s. It is also a good example of dualization since the new alternatives to training increase stratification in the VET system (vocational education and training system).

Additionally, the rise of the transition system shows how the expansion of the role of markets can go along with or even require re regulation. If the state in par ticular the federal government and the Federal Employment Agency had not set up the various training and labour measures of the transition system in order to cushion the effects of market decisions, it would have been much harder to sustain the dele gation of training to employers, both politically and economically. It is only because state actors were willing to establish a framework of expensive and more or less ef fective public policies that the delegation of quasi public obligations such as training to market actors remained politically feasible.

The Certification of Occupational Skills

Traditionally, the system of training occupations in Germany was undifferentiated. With a few exceptions, all officially recognized training occupations stipulate a train ing period of at least three years until the vocational degree of a skilled worker/journeyman is awarded. In collective wage bargaining agreements, vocational 
degrees were linked to pay scale groupings, independent of the specific job the per son in question performed (Busemeyer 2009: 185). In the 1980s and 1990s employ ers, politically supported by the conservative federal government, demanded a greater degree of differentiation within the system of training occupations so that firms would be able to better match trainees with jobs in increasingly differentiated internal labour markets in order to prevent investments in training above need. Unions, of course, opposed a further differentiation because they feared wage competition be tween workers and a general downward spiralling effect on training and wages. The government, still committed to the principle of corporatist compromise, refrained from following through with their political demands (Busemeyer 2009: 187).

This situation changed dramatically in 2003, when the then Minister for Labour and Economic Affairs, Wolfgang Clement (SPD), decided to side with employers and decreed the introduction of new two year apprenticeships against the outspoken opposition of the trade unions (DGB 2006: 52). Since then several more short term apprenticeships have been introduced, both in new economic sectors such as services as well as in the core sectors of manufacturing and chemicals. This development is transformative because the new, short term apprenticeships are positioned alongside longer, more demanding training profiles and specifically designed in such a way as to allow trainees to receive credit for their earlier training. This significantly alters the relative costs and benefits of training for firms: Employers can hire apprentices for the shorter, less demanding apprenticeships and then decide later whether they should continue to train a given person in a more demanding occupation, lowering the risk of "misguided" investments in human capital. Hence, again, the structure of the vocational training system is being transformed in a way that is reminiscent of market relationships as the training needs of firms are prioritized. Training according to the individual skill needs of firms instead of collectively defined standards of a particular occupation is a significant departure from the cherished occupational principle.

From the perspective of employers and governmental policy makers, this trans formation might be seen as an example of a successful adaptation of the system (see also Bosch 2010), bringing it closer in line with the training and employment needs of firms. Independent of this question, the transformative shift from the undifferenti ated system of training occupations that existed before to a catalogue of training occupations that is much more differentiated can be interpreted as a process of liber alization: The new system mirrors existing inequalities in ability to a stronger extent than the old system; it brings the system of training occupations closer to the needs of firms demanding more flexibility and differentiation.

\section{Changes in the Corporatist Framework of Regulated Self-Regulation}

The role of the state, i.e. the federal government and/or the Federal Institute for Vocational Education and Training (BIBB), in the neo corporatist framework of the vocational training was to act as an arbiter and moderator of conflicts between the social partners. The state refrained from intervening more actively, delegating deci sions to the social partners and promoting consensual bargaining solutions. As it was based on a broad cross class compromise and in order to prevent collective good problems in training, the regulatory framework actually included some real con straints for training firms (e.g. firms, when deciding to hire apprentices, are obliged to 
train according to the established standard). In the last years this framework has been transformed in two important ways:

First, the institutional (in the sense of legal) framework of vocational training was deregulated in an incremental, but transformative manner. For one, the federal government loosened legal obligations for firms to give credit for prior learning. In the 1970s a set of ordinances were enacted to regulate the recognition of prior learn ing in school based courses (Berufsvorbereitungsjahr, Berufsgrundschuljabr) for regular apprenticeships. As a consequence apprentices could, for example, complete the first part of their training in a vocational school and then continue in firm based training without having to start from zero again. Since the beginning, firms acting as institu tional entrepreneurs tried to circumvent these regulations. For instance, firms re fused to offer training places to young people, if they did not agree to start over from the beginning (see Busemeyer 2009: 103). The reform of the vocational training law (BBiG) in 2005 abolished all ordinances regulating the obligatory recognition of prior learning. After a transition period, prior learning in vocational schools is now only recognized when both the apprentice and the training firm agree to do so. Hence, the new law maintains the firm's flexibility to shorten apprenticeship training by recog nizing prior learning, but it does not entail a guarantee for the apprentice to get credit for prior learning.

Second, the formerly consensual corporatist way of bargaining between the so cial partners is increasingly replaced with conflictual bargaining, indicating the fraying of the supporting cross class coalition of the neo corporatist era (see also Streeck 2005, 2009; Höpner 2007; Vail 2008). Conflicts between unions and business are increasingly bitter, in particular over the issues of two year apprenticeships where the powerful trade unions IG Metall and ver.di refuse to participate in the reform of occupational profiles out of protest (Busemeyer 2009: 191) and modularization. In addition, fractions are emerging within the respective camps of business and labour. Among unions, the union for teachers, education professionals and scientists (GEW) is the only one supporting the expansion of school based vocational training, whereas the industrial unions (e.g., the IG Metall and the IG BCE) want to preserve the supe riority of firm based apprenticeship training (Busemeyer 2009: 199). When the gov ernment coalition of Social Democrats and Greens discussed the introduction of a training levy in response to the crisis on the apprenticeship market, the conflicts between unions and within the Social Democratic Party were a major reason why the levy did not come into being (Busemeyer 2009: 154 155). In the employers' camp, the cleavage between small and large enterprises as well as between the crafts and the industrial sectors are as visible as in the case of social policy (see above). Small firms are overburdened with implementing the ever more ambitious occupational profiles and, as a consequence, drop out of training. At the same time, small firms benefit less from the increasing leeway for specialization that the more flexibilized and deregu lated vocational training system offers (Busemeyer 2009: 188 189). Because of the increasing conflicts between business and labour, but also within the respective camps, the state is increasingly forced to step in as the ultimate arbiter and banker of last resort (Streeck 2005, 2009). The disorganization of collective interests (Höpner 2007; Streeck 2009) is therefore intrinsically linked to the specific character of liber alization in coordinated market economies such as Germany, where deregulation 
leads in a seemingly paradoxical way to a re assertion of the hierarchy between states and markets that neo corporatism was supposed to overcome.

All in all, these examples show how the corporatist framework of the vocational training system is being challenged on a number of fronts. The deregulation of the legal framework indicates how training is re configured in a way that caters more to the individual needs of training firms. In our view, this process can and should be conceptualized as a process of liberalization because it disburdens existing institu tions from collective obligations and leads to a re structuring of the vocational train ing system mirroring market relationships rather than public concerns. The trigger for the liberalization process was the accumulation of negative side effects in the form of an excess demand for training places. Governmental policy makers decided to pursue liberalization instead of alternatives such as strengthening school based training be cause they wanted to maintain the commitment of employers to vocational training. A consequence of liberalization and deregulation is the increasing institutional and socio economic stratification of the VET system.

\section{Conclusions}

Summing up, the examples of social policy and vocational training document a proc ess of liberalization in the sense that the institutions of coordinated capitalism are reformed in a particular way: They provide less protection against market forces ("re commodification") and where institutions provide concrete benefits to business as in the case of vocational training, they are reformed in order to bring them closer to the specific demands of business. The point we want to emphasize here is that liberaliza tion is not necessarily driven by exogenous forces, although these forces certainly played a role as well and can act as catalysts and triggers of change. We are primarily concerned with identifying the endogenous driving forces of liberalization. Our ar gument is that the corporatist cross class compromise that lies at the heart of coordi nated capitalism in Germany should not be regarded as a self reinforcing political equilibrium, but as a brittle political arrangement fraught with inherent tensions. The very institutional solutions that sustained cross class compromise in the past have contributed to the accumulation of negative side effects over time that trigger a pol icy response by the government after a threshold is reached.

We suggest to interpret this transformative change as a process of institutional exhaustion. This process differs from other patterns of institutional change identified by Streeck and Thelen (2005) with regard to an important aspect: The supporting coalition of actors does not primarily aim at abolishing existing or creating new insti tutions. We also emphasize that institutional exhaustion is not a new concept in insti tutional analysis, but that this concept should be revisited and refined. In detail, the main features of institutional exhaustion are as follows: First, exhaustion is a causal mechanism of institutional change through which endogenously generated negative feedback effects trigger institutional change. Second, there is interaction between endogenous and exogenous sources of change because exogenous factors affect the timing of change. Third, exhaustion does not lead to breakdown, displacement or decay because institutions do not evaporate as long as they remain politically sustain 
able. Consequently, and fourth, exhaustion also differs from layering, conversion or drift because policy makers are actively engaged in the process of change but never theless they don't necessarily add new rules or aim at changing the functions of old institutions (see the introduction to this volume). Further research can try to assert whether exhaustion can also be found in other policy areas, such as labour market policy or health care (see the contribution by Gerlinger in this special issue) or in other country contexts.

\section{References}

Baethge, Martin; Solga, Heike; Wieck, Markus (2007): Berufsbildung im Umbruch: Signale eines überfälligen Aufbruchs. Berlin: Friedrich Ebert Stiftung.

Bosch, Gerhard (2010): "The Revitalization of the Dual System of Vocational Training in Germany", in: Gerhard Bosch; Jean Charest (eds.): Vocational Training: International Per spectives. New York: Routledge, 84109.

Bundesregierung (1983): Unterrichtung durch die Bundesregierung: Berufsbildungsbericht 1983, BT Drucksache 10/334.

Busemeyer, Marius R.: (2009): Wandel trotz Reformstau: Die Politik der beruflichen Bildung seit 1970. Frankfurt/Main: Campus.

Busemeyer, Marius R.: (2012) Reformperspektiven der beruflichen Bildung: Erkenntnisse aus dem internationalen Vergleich. Berlin and others: Friedrich Ebert Stiftung.

Busemeyer, Marius R. and Trampusch, Christine (2012): "Introduction: The Comparative Political Economy of Collective Skill Formation", in: Marius R. Busemeyer; Christine Trampusch (eds): The Political Economy of Collective Skill Formation. Oxford: Oxford University Press, 338.

Campbell, John L. (2004): Institutional Change and Globalization. Princeton and Oxford: Prince ton University Press.

Cioffi, John W.; Höpner, Martin (2006): "The Political Paradox of Finance Capitalism: Inter ests, Preferences, and Center Left Party Politics in Corporate Governance Reform”, Politics \& Society 34: 463502

Clemens, Clay (2007): “Two steps Forward, One Step Back: Merkels' CDU/CSU and the Politics of Welfare State Reform“, German Politics 16: 222246.

Deeg, Richard (2001): Institutional Change and the Uses and Limits of Path Dependency: The Case of German Finance', MPIfG Discussion Paper 01/6, Cologne.

DGB, Deutscher Gewerkschaftsbund (2006): Beschlüsse zur Bildungspolitik: 18. Ordentlicher DGB Bundeskongress, 22. 26.05.2006. Berlin: DGB Bundesvorstand.

Eichhorst, Werner; Kaiser, Lutz C. (2006): The German Labor Market: Still Adjusting Badly?, IZA Discussion Paper No. 2215.

Elster, Jon (1989): Nuts and Bolts for the Social Sciences. Cambridge: Cambridge University Press.

Euler, Dieter; Severing, Eckart (2006): Flexible Ausbildungswege in der Berufsbildung. Nürnberg, St. Gallen and Bonn: Bundesministerium für Bildung und Forschung, Innovationskreis berufliche Bildung.

Gerring, John (2007): Case Study Research. Principles and Practices. Cambridge: Cambridge University Press. 
Hall, Peter A.; Soskice, David (2001): “An Introduction to Varieties of Capitalism”, in: Peter A. Hall; David Soskice (eds): Varieties of Capitalism: The Institutional Foundations of Com parative Advantage. Oxford: Oxford University Press, 168.

Hall, Peter A.; Thelen, Kathleen (2009): "Institutional Change in Varieties of Capitalism", Socio Economic Review 7: 734

Hassel, Anke; Schiller, Christoph (2009): Bringing the State Back In The Role of Fiscal Federalism for Welfare Restructuring. Paper prepared for the 21 st annual meeting of SASE, Paris, July 16 18, 2009.

Höpner, Martin (2007): Coordination and Organization: The Two Dimensions of Nonliberal Capitalism, MPIfG Discussion Paper 07(12), Cologne.

Mahoney, James (2010): “After KKV: The New Methodology of Qualitative Research”, World Politics 62: 12047.

Mahoney, James; Thelen, Kathleen (2010): “Chapter 1. A Theory of Gradual Institutional Change", in: James Mahoney; Kathleen Thelen (eds): Explaining Institutional Change: Ambiguity, Agency, and Power. New York: Cambridge University Press, 137.

Manow, Philip; Seils, Eric (2000): “Adjusting Badly. The German Welfare State, Structural Change, and the Open Economy", in: Fritz W. Scharpf; Vivien Schmidt (eds): Welfare and Work in the Open Economy. Volume II. Diverse Responses to Common Challenges. Oxford: Oxford University Press, 264307.

Mares, Isabela (2003): The Politics of Social Risk: Business and Welfare State Development. Cambridge: Cambridge University Press.

Palier, Bruno; Martin, Claude (2007): "Editorial Introduction. From 'a Frozen Landscape' to Structural Reforms: The Sequential Transformation of Bismarckian Welfare Systems", Social Policy \& Administration 41: 535554.

Palier, Bruno; Thelen, Kathleen (2010): "Institutionalizing Dualism: Complementarities and Change in France and Germany", Politics \& Society 38: 119248.

Pierson, Paul (2004): Politics in Time. History, Institutions, and Social Analysis. Princeton, Oxford: Princeton University Press.

Polanyi, Karl (1997) [1944]: The Great Transformation: Politische und ökonomische Ursprünge von Gesellschaften und Wirtschaftssystemen, 4th edition. Frankfurt/Main: Suhrkamp.

Schludi, Martin (2005): The Reform of Bismarckian Pension Systems: A Comparison of Pension Politics in Austria, France, Germany, Italy and Sweden. Amsterdam: Amsterdam University Press.

Skocpol, Theda; Somers, Margaret (1980): "The uses of comparative history in macrosocial inquiry", Comparative Studies in Society and History 22: 174197.

Soskice, David (1994): "Reconciling Markets and Institutions: The German Apprenticeship System", in: Lisa M. Lynch (ed.): Training and the Private Sector: International Comparisons. Chicago: University of Chicago Press, 2560.

Streeck, Wolfgang (1992): Social Institutions and Economic Performance: Studies of Industrial Relations in Advanced Capitalist Economies. London: Sage.

Streeck, Wolfgang (2003): From State Weakness as Strength to State Weakness as Weakness: Welfare Corporatism and the Private Use of the Public Interest, MPIfG Working Pa per $03 / 2$, Cologne.

Streeck, Wolfgang (2005): Institutional Change in France and Germany: Introduction, unpub lished manuscript. Cologne: Max Planck Institute for the Study of Societies.

Streeck, Wolfgang (2007): Endgame? The Fiscal Crisis of the German Welfare State, MPIfG Discussion Paper 07/7, Cologne. 
Streeck, Wolfgang (2009): Re Forming Capitalism: Institutional Change in the German Political Econ omy. Oxford: Oxford University Press.

Streeck, Wolfgang; Thelen, Kathleen (2005): "Introduction: Institutional change in advanced political economies", in: Wolfgang Streek; Kathleen Thelen (eds.): Beyond continuity: In stitutional change in advanced political economies. Oxford: Oxford University Press, 139.

Streeck, Wolfgang, Weber, Hajo; Hilbert, Josef; von Kevelaer, Karl Heinz; Maier, Friederike (1987): Steuerung und Regulierung der beruflichen Bildung: Die Rolle der Sozialpartner in der Ausbil dung und beruflichen Weiterbildung in der Bundesrepublik. Deutschland. Berlin: edition sigma.

Thelen, Kathleen (2004): How institutions evolve. The political economy of skills in Germany, Britain, the United States and Japan. New York: Cambridge University Press.

Thelen, Kathleen (2012): "Varieties of Capitalism: Trajectories of Liberalization and the New Politics of Social Solidarity", Annual Review of Political Science 15: 137159.

Thelen, Kathleen and Busemeyer, Marius R. (2012): "Institutional Change in German Voca tional Training: From Collectivism towards Segmentalism”, in: Marius R. Busemeyer; Christine Trampusch (eds.): The Political Economy of Collective Skill Formation. Oxford: Oxford University Press, 68100.

Thelen, Kathleen, Kume, Ikuo (1999): "The Effects of Globalization on Labor Revisited: Lessons from Germany and Japan”, Politics \& Society 27: 477505.

Trampusch Christine (2005a): "From Interest Groups to Parties. The Change in the Career Patterns of the Legislative Elite in German Social Policy", German Politics 14: 1432.

Trampusch, Christine (2005b): "Institutional Resettlement: The Case of Early Retirement in Germany", in: Wolfgang Streeck; Kathleen Thelen (eds.): Beyond Continuity: Institutional Change in Advanced Political Economies. Oxford: Oxford University Press, 203228.

Trampusch, Christine (2009): Der erschöpfte Sozialstaat. Transformation eines Politikfeldes. Frank furt/Main: Campus.

Trampusch, Christine (2010): "Employers, the State, and the Politics of Institutional Change. Vocational Education and Training Regimes in Austria, Germany and Switzerland", European Journal of Political Research 49: 545573.

Vail, Marki I. (2008): “From 'Welfare Without Work' to 'Buttressed Liberalization': The Shift ing Dynamics of Labor Market Adjustment in France and Germany", European Journal of Political Research 47: 334358. 


\section{Contact Details}

Prof. Dr. Marius R. Busemeyer

University of Konstanz

Fach D 79

78457 Konstanz

E Mail: marius.busemeyer@uni konstanz.de

Marius R. Busemeyer (*1978) is a Professor of Political Science at the University of Konstanz. He studied political science, economics and public law and received his PhD (Dr. rer. pol.) in 2006 from the University of Heidelberg. His research focuses on comparative political economy, welfare states, public spending, social democratic parties and theories of institutional change.

Prof. Dr. Christine Trampusch

University of Cologne

Cologne Center for Comparative Politics (CCCP)

Herbert Lewin Straße 2

50931 Köln

E Mail: christine.trampusch@uni koeln.de

Christine Trampusch $(* 1970)$ is a Professor of International Comparative Political Economy and Economic Sociology at the Cologne Center for Comparative Politics, University of Cologne. She studied political science and economics and received her PhD (Dr. disc. Pol) in 2000 from the Georg August University of Göttingen. In her research, she mainly employs historical institutional and comparative methods in order to analyze the processes, contents, and struc tures of policies that regulate labor and financial markets. 